\title{
Diamorphine infusion in the preterm neonate
}

\author{
A C Elias-Jones, D A Barrett, N Rutter, P N Shaw, S S Davis
}

\begin{abstract}
The effects of diamorphine were studied in 34 premature neonates who were given a loading dose of $50 \mu \mathrm{g} / \mathrm{kg}$ of diamorphine followed by a constant rate intravenous infusion of $15 \mu \mathrm{g} / \mathrm{kg} /$ hour. Small but significant falls were noted in blood pressure (at 30 minutes) and heart rate (at 30 minutes, six hours, and 12 hours) after administration of diamorphine, but these did not appear to cause any clinical deterioration and were thought to be related to the sedative effect of the drug. A significant fall in respiration rate at 30 and 60 minutes reflected the desired intention to encourage synchronisation of the infants' breathing with the ventilator. The mean (SD) plasma concentration of morphine measured during the infusion at steady state was $62.5(22.8) \mathrm{ng} / \mathrm{ml}$ (range 20 to $98 \mathrm{ng} / \mathrm{ml}$ ). The data suggest that this dosage regimen of diamorphine is safe. It results in plasma concentrations of morphine in the premature neonate which are comparable with those that are known to provide effective analgesia in the child and adult.
\end{abstract}

Until recently it was believed that newborn infants did not feel pain and consequently the use of analgesics in neonatal units was limited. It is now accepted that pain pathways are well developed in newborn babies and that an acute stress response to pain is readily detected as hormonal and metabolic changes. ${ }^{1}$ There is good evidence that the use of opioid analgesic infusions reduces this stress response in preterm infants undergoing surgery ${ }^{2}$ and as a result there is increasing use of opioids as analgesia in neonatal units. In addition, opioids are now being used more frequently as a sedative in mechanically ventilated newborn infants. This practice is believed to improve the synchronisation between the infant's own breathing and the ventilator. As well as these potentially beneficial effects, opioids do have unwanted side effects ${ }^{3} 4$ and care must be taken to ensure that the chosen dosage regimen does not cause unnecessary danger to the patient.

Diamorphine (3,6-diacetylmorphine) is a synthetic derivative of the opioid morphine. In man, diamorphine is rapidly metabolised to 6acetylmorphine and morphine ${ }^{5}$ and it is generally accepted that diamorphine acts as a prodrug for its active metabolites. ${ }^{6}$ Diamorphine has been reported to be a faster acting and more potent analgesic than morphine, features thought to derive from its more rapid uptake into the brain due to its increased lipid solubility compared with morphine. ${ }^{8}$ In addition, the increased aqueous solubility of diamorphine compared with morphine is advantageous for intravenous administration. Diamorphine infusion is currently in use clinically to treat both mature and premature newborns, the diamorphine dosing regimen being based on that for morphine. This study was designed to evaluate the effect of diamorphine and to establish the safety of our current dose regimen in the premature neonate.

\section{Patients and methods}

PATIENTS

Thirty four neonates of gestational age 26 to 40 weeks (mean (SD) of $31.0(4 \cdot 0)$ weeks), postnatal age 1 to 37 days (mean (SD) $3 \cdot 0(6 \cdot 1)$ days) and birth weight 740 to $3560 \mathrm{~g}$ (mean (SD) 1610 (710) $\mathrm{g}$ ) were studied. Thirty of the infants had respiratory distress syndrome, and the remaining four were diagnosed as suffering from apnoea, perforated caecum, tracheooesophageal fistula, and meconium aspiration. Approval for the study was obtained from the hospital ethics committee and informed consent was given by parents.

\section{DOSE REGIMEN AND OBSERVATIONS}

Patients received a loading dose of diamorphine of $50 \mu \mathrm{g} / \mathrm{kg}$ given as an intravenous infusion over 30 minutes, followed by a continuous infusion at a rate of $15 \mu \mathrm{g} / \mathrm{kg} /$ hour. The loading dose and the continuous infusion rate were based on the lowest recommended doses for morphine administration, to take into account the reported higher potency of diamorphine compared with morphine. ${ }^{9-12}$ Diamorphine hydrochloride was diluted in $10 \%$ dextrose and infused at a rate of $0.5 \mathrm{ml} /$ hour to keep the volume of fluid administered to a minimum. For clinical reasons certain patients received a different loading dose or infusion rate of diamorphine, and in some patients the infusion rate was changed during the study. The duration of the diamorphine infusion ranged from 14 to 149 hours (mean (SD) 59.4 (32.9) hours).

Observations were carried out on 34 infants, 20 of whom were studied closely in the first 24 hours after the loading dose of diamorphine, the remainder had normal regular nursing observations during the infusion and for 24 hours after the end of the infusion. In the closely studied group, measurements of mean blood pressure, heart rate, respiratory rate, temperature, arterial $\mathrm{pH}$, oxygen tension $\left(\mathrm{Po}_{2}\right)$, carbon dioxide tension $\left(\mathrm{PCO}_{2}\right)$, and blood glucose concentration were made before the loading dose of diamor- 
phine and at 30 minutes, one, six, 12, and 24 hours after the dose.

\section{BLOOD SAMPLING AND ANALYSIS}

Arterial blood samples $(0.5 \mathrm{ml})$ were collected after the loading dose, two to five times during the continuous infusion, and serially 10 times in the 24 hours after discontinuation of the diamorphine infusion. Plasma was separated and stored at $-30^{\circ} \mathrm{C}$ until analysed. Plasma from eight subjects was analysed by a high pressure liquid chromatography (HPLC) method for morphine and 6-acetylmorphine. ${ }^{13}$ This HPLC method involved solid phase extraction, fluorescent derivatisation, and fluorescence detection of morphine and 6acetylmorphine in plasma. The limit of quantitation for the assay was $10 \mathrm{ng} / \mathrm{ml}$ for morphine and $25 \mathrm{ng} / \mathrm{ml}$ for 6-acetylmorphine $(0.1 \mathrm{ml}$ plasma volume). The remaining samples were analysed by a Coat-A-Count radioimmunoassay (RIA) method (Diagnostic Products Ltd) which was highly specific for morphine. The RIA method showed low cross reactivity $(<0.5 \%)$ with diamorphine, 6-acetylmorphine, and other metabolites of morphine. The steady state concentration was taken as the morphine plasma concentration at the end of the diamorphine infusion, or as a mean of values during infusion where these were within $\pm 10 \%$ of each other. Good agreement was achieved between the RIA and HPLC methods. During the study, drugs other than diamorphine were administered to the infants, the most common being benzylpenicillin, gentamicin, flucloxacillin, metronidazole, and cefotaxime. There was no evidence that these drugs interfered with the assay for morphine in plasma.

\section{Results}

Table 1 shows the mean values compared with the predose values for heart rate, mean blood pressure, respiratory rate, blood $\mathrm{pH}$, blood $\mathrm{Po}_{2}$, blood $\mathrm{PCO}_{2}$, and blood glucose. Blood pressure showed a transient reduction at 30 minutes $(p<0.03)$ which was not maintained at one, six, 12 , or 24 hours. There was a significant fall $(p<0.03)$ in heart rate at 30 minutes and at six and 12 hours but significant differences were not observed at 60 minutes, 12 , or 24 hours. A significant fall $(p<0.01)$ in respiration rate was noted at both 30 and 60 minutes after infusion but this was not sustained later in the infusion. No significant differences were observed in arterial $\mathrm{pH}, \mathrm{PcO}_{2}, \mathrm{Po}_{2}$, or in blood glucose for the duration of the study. Table 2 shows the
Table 2 Mean percentage changes in heart rate, mean blood pressure, and respiratory rate in 20 preterm infants after diamorphine loading and infusion. Each value is mean $(S D)$

\begin{tabular}{|c|c|c|c|}
\hline $\begin{array}{l}\text { Time from } \\
\text { baseline } \\
\text { measurement } \\
\text { (hours) }\end{array}$ & $\begin{array}{l}\% \text { Change in } \\
\text { heart rate }\end{array}$ & $\begin{array}{l}\text { \% Change in } \\
\text { mean blood } \\
\text { pressure }\end{array}$ & $\begin{array}{l}\% \text { Change in } \\
\text { respiratory } \\
\text { rate }\end{array}$ \\
\hline $\begin{array}{l}0 \cdot 5 \\
1 \\
6 \\
12 \\
24\end{array}$ & $\begin{array}{l}-2 \cdot 3(4 \cdot 5)^{*} \\
-2 \cdot 0(6 \cdot 1) \\
-6 \cdot 1(9 \cdot 5)^{* *} \\
-5 \cdot 2(8 \cdot 3)^{*} \\
-4 \cdot 2(11 \cdot 7)\end{array}$ & $\begin{aligned} &-6.3(11 \cdot 6)^{*} \\
&-4.5(11.8) \\
&-3.4(16 \cdot 3) \\
&-2.6(17 \cdot 2) \\
& 4.3(23 \cdot 7)\end{aligned}$ & $\begin{aligned}-6 \cdot 6 & (9 \cdot 5)^{* *} \\
-8 \cdot 2(12 \cdot 0)^{* *} & =(23 \cdot 2) \\
-1.7 & (23 \cdot 6(30 \cdot 4) \\
5.0 & (37 \cdot 4)\end{aligned}$ \\
\hline
\end{tabular}

Paired $\iota$ test: ${ }^{*} \mathrm{p}<0.05,{ }^{* *} \mathrm{p}<0.01$.

mean percentage changes in heart rate, mean blood pressure, and respiratory rate: similar small but significant falls were noted.

Morphine was detected in the plasma of all subjects but no 6-acetylmorphine was detected in any of the plasma samples analysed by the HPLC method. The mean (SD) steady state morphine concentration during diamorphine infusion was $62.5(20.8) \mathrm{ng} / \mathrm{ml}(\mathrm{n}=19)$ with the plasma concentrations ranging between 20 and $98 \mathrm{ng} / \mathrm{ml}$ for those patients who received diamorphine at an infusion rate of $15 \mu \mathrm{g} / \mathrm{kg} /$ hour.

\section{Discussion}

Although small, significant falls in heart rate and mean blood pressure were noted during the diamorphine infusion, they were not associated with any clinical deterioration. They may have been related to the reduction of stress in the infants caused by the sedative and analgesic effects of the drug rather than being due to unwanted side effects. Although the mean blood pressure and heart rate of patients in the study are towards the limit of desirable values, they still fall within the normal range for premature infants. ${ }^{14}$ Similar but more appreciable reductions in heart rate and blood pressure have been noted by other workers studying opioid drugs, with particular concern if the dose was given as an intravenous bolus. ${ }^{34}$ The loading dose was given as a slow bolus over 30 minutes in our study, perhaps preventing any noticeable changes in these cardiovascular measurements.

The fall in respiration rate reflected the desired intention to settle the patients and encourage synchronisation of the infants' own efforts with the ventilator, which was achieved in 19 of the 20 babies studied by one hour after starting the diamorphine infusion. In this study direct measures of analgesic and sedative benefit were not made, although the subjects were noted to be more relaxed after the introduction

Table 1 Effects of diamorphine infusion in the preterm newborn. Each value is the mean (SD) of observations in 20 infants

\begin{tabular}{|c|c|c|c|c|c|c|c|}
\hline $\begin{array}{l}\text { Time of measurement } \\
\text { (hours after start) }\end{array}$ & $\begin{array}{l}\text { Heart rate } \\
\text { beats/minute }\end{array}$ & $\begin{array}{l}\text { Mean blood } \\
\text { pressure } \\
(\mathrm{mmHg})\end{array}$ & $\begin{array}{l}\text { Respiratory } \\
\text { rate (breaths/ } \\
\text { minute) }\end{array}$ & $p H$ & $\begin{array}{l}\mathrm{PaO}_{2} \\
(\mathrm{kPa})\end{array}$ & $\begin{array}{l}\mathrm{PaCO}_{2} \\
(\mathrm{kPa})^{-}\end{array}$ & $\begin{array}{l}\text { Blood glucose } \\
\text { (mmolll) }\end{array}$ \\
\hline $\begin{array}{l}\text { Predose } \\
0.5 \\
1 \\
6 \\
12 \\
24\end{array}$ & $\begin{array}{l}152 \cdot 5(14 \cdot 1) \\
148 \cdot 9^{*}(15 \cdot 3) \\
149 \cdot 8(16 \cdot 8) \\
144 \cdot 2^{*}(16 \cdot 6) \\
144 \cdot 0^{*}(12 \cdot 7) \\
144 \cdot 2(13 \cdot 0)\end{array}$ & $\begin{array}{l}38 \cdot 8(7 \cdot 4) \\
36 \cdot 5 *(8 \cdot 5) \\
37 \cdot 1(8 \cdot 4) \\
37 \cdot 2(5 \cdot 5) \\
37 \cdot 6(6 \cdot 4) \\
40 \cdot 3(7 \cdot 9)\end{array}$ & $\begin{array}{l}75 \cdot 3(16 \cdot 1) \\
70 \cdot 3^{*}(17 \cdot 4) \\
68 \cdot 9^{*}(17 \cdot 3) \\
72 \cdot 0(19 \cdot 3) \\
70 \cdot 8(17 \cdot 8) \\
72 \cdot 8(19 \cdot 1)\end{array}$ & $\begin{array}{l}7 \cdot 20(0 \cdot 10) \\
7 \cdot 23(0 \cdot 11) \\
7 \cdot 22(0 \cdot 11) \\
7 \cdot 21(0 \cdot 11) \\
7 \cdot 24(0 \cdot 10) \\
7 \cdot 22(0 \cdot 11)\end{array}$ & $\begin{array}{l}7 \cdot 1(2 \cdot 4) \\
6 \cdot 9(2 \cdot 3) \\
7 \cdot 1(2 \cdot 2) \\
8 \cdot 4(3 \cdot 4) \\
7 \cdot 8(1 \cdot 3) \\
8 \cdot 0(1 \cdot 8)\end{array}$ & $\begin{array}{l}6.5(1.8) \\
6.0(1.9) \\
5.8(1.8) \\
6.5(1.7) \\
6.8(1.9) \\
7.2(2.6)\end{array}$ & $\begin{array}{l}4 \cdot 3(1 \cdot 6) \\
4 \cdot 2(1 \cdot 7) \\
4 \cdot 3(2 \cdot 0) \\
4 \cdot 7(2 \cdot 0) \\
4 \cdot 2(1 \cdot 6) \\
3 \cdot 7(1 \cdot 7)\end{array}$ \\
\hline
\end{tabular}

${ }^{*}$ Significant difference from predose value (two tailed Student's $t$ test, $\mathrm{p}<0 \cdot 03$ ). 
of the diamorphine infusions. Similarly, exact measurements of urine and stool outputs were not made, although urine retention and constipation are described with opiates.

The range of plasma morphine concentrations of between 20 and $98 \mathrm{ng} / \mathrm{ml}$ (mean $62.5 \mathrm{ng}$ / ml) compares with reported minimum concentrations required for effective analgesia in children and adults of between 20 and $65 \mathrm{ng} /$ $\mathrm{ml} .^{12} 1516$ Thus it appears that the diamorphine infusion rate of $15 \mu \mathrm{g} / \mathrm{kg} / \mathrm{hour}$ used in the study produces an effective plasma concentration of morphine, although this does not necessarily imply effective analgesia. It is not known whether the reported therapeutic plasma concentrations of analgesics in children and adults apply to newborn infants nor whether there is an increased sensitivity to the side effects of opioid drugs. In addition, there is no information on the extent to which the active metabolite of diamorphine, 6-acetylmorphine, enhances the analgesic effect of the main active metabolite, morphine. In this study no 6acetylmorphine was detected in plasma after diamorphine administration but this was probably a result of the limited sensitivity of the assay. We are planning further investigations to clarify the relationship between plasma concentrations of the active diamorphine metabolites, morphine and 6-acetylmorphine, and the analgesic effect in the neonate. Morphine pharmacokinetics were examined in the present study and are reported. elsewhere. ${ }^{17}$

Our study has shown that diamorphine can be safely given to preterm newborn infants as a combination of a slowly administered loading dose and a continuous infusion. It appeared to be effective, and resulted in plasma morphine concentration which in a child or adult would provide adequate analgesia.
The assitance of Dr D Shortland in the clinical aspects of the study is acknowledged. D A Barrett was funded by Ciba-Geigy (USA).

Anand KJS, Hickey PR. Pain and its effects in the human neonate and fetus. $N$ Engl $\mathcal{f}$ Med 1987;317:1321-9.

2 Anand KJS, Sippel WG, Aynsley-Green A. Randomised trial of fentanyl anaesthesia in preterm babies undergoing surgery. Lancet 1987;i:243-8.

3 Miall-Allen VM, Whitelaw AGL. Effects of pancuronium and pethidine on heart rate and blood pressure in ventilated infants. Arch Dis Child 1987;62:1179-80.

4 Marlow N, Weindling AM, Cooke RWI. Hazards of analgesia for newborn infants. Arch Dis Child 1988;63:1293.

5 Inturrisi CE, Max MB, Fley KM, Schultz M, Shin SU, Houde RW. The pharmacokinetics of heroin in patients with chronic pain. $N$ Engl 7 Med 1984;310:1213-7.

6 Inturrisi CE, Schultz M, Shin S, Umans JG, Angel L, Simon EJ. Evidence from opiate binding studies that heroin acts EJ. Evidence from opiate binding studies that

7 Boerner U, Abbot S, Roe RL. The metabolism of morphine and heroin in man. Drug Metab Rev 1975;4:39.

8 Bruce-Scott D, ed. Diamorphine. England: WoodheadFaulkener, 1988 .

9 Bhat R, Chari G, Gulati A, Aldana O, Velamati R, Bhargava $H$. Pharmacokinetics of a single dose of morphine in preterm infants during the first week of life. $\mathcal{F}$ Pediatr 1990; 117:477-81.

10 Koren G, Butt W, Chinyanga H, Soldin S, Tan Y, Pape K. Postoperative morphine infusion in newborn infants assessment of disposition characteristics and safety. f Pediatr 1985;107:963-7.

11 Mercurio M, Nelli E, Gettner P, Sherwonit E, Williams J, Ehrenkranz R. Morphine pharmacokinetics in preterm newborns. Pediatr Res 1989;25:71A.

12 Dahlstrom B, Boline P, Feychting H, Noack G, Paalzour L. Morphine kinetics in children. Clin Pharmacol Ther 1979. 26:354-65.

13 Barrett DA, Shaw PN, Davis SS. Determination of morphine and 6-acetylmorphine in plasma by high-performance liquid chromatography with fluorescence detection. liquid chromatography with

14 Biller JA, Yagr AM (eds). The Harriet Lane handbook. 9th Ed. Chicago: Year Book Medical Publishers, 1981:56.

15 Berkowitz BA, Ngai SH, Yang JC, Hempstead J, Spector S The disposition of morphine in clinical patients. Clin The disposition of morphine in

16 Dahlstrom B, Tamsen A, Paalzow L, Hartvig P. Patient controlled analgesic therapy. Part IV: pharmacokinetic and analgesic plasma concentrations of morphine. Clin Pharmacokinet 1982;7:266-79.

17 Barrett DA, Elias-Jones AC, Rutter N, Shaw PN, Davis SS Morphine kinetics after diamorphine infusion in premature neonates. Br f Clin Pharmacol 1991 (in press). 